\title{
Laparoscopic and open resection for colorectal cancer: an evaluation of cellular immunity
}

\author{
Chen Huang ${ }^{1 \dagger}$, Renxiang Huang ${ }^{2 \dagger}$, Tao Jiang ${ }^{1}$, Kejian Huang ${ }^{1}$, Jun Cao ${ }^{1}$, Zhengjun Qiu ${ }^{1 *}$
}

\begin{abstract}
Background: Colorectal cancer is one kind of frequent malignant tumors of the digestive tract which gets high morbidity and mortality allover the world. Despite the promising clinical results recently, less information is available regarding the perioperative immunological effects of laparoscopic surgery when compared with the open surgery. This study aimed to compare the cellular immune responses of patients who underwent laparoscopic(LCR) and open resections(OCR) for colorectal cancer.
\end{abstract}

Methods: Between Mar 2009 and Sep 2009, 35 patients with colorectal carcinoma underwent LCR by laparoscopic surgeon. These patients were compared with 33 cases underwent conventional OCR by colorectal surgeon. Clinical data about the patients were collected prospectively. Comparison of the operative details and postoperative outcomes between laparoscopic and open resection was performed. Peripheral venous blood samples from these 68 patients were taken prior to surgery as well as on postoperative days(POD) 1, 4 and 7. Cell counts of total white blood cells, neutrophils, lymphocyte subpopulations, natural killer(NK) cells as well as CRP were determined by blood counting instrument, flow cytometry and hematology analyzer.

Results: There was no difference in the age, gender and tumor status between the two groups. The operating time was a little longer in the laparoscopic group $(P>0.05)$, but the blood loss was less $(P=0.039)$. Patients with laparoscopic resection had earlier return of bowel function and earlier resumption of diet as well as shorter median hospital stay $(P<0.001)$. Compared with OCR group, cell numbers of total lymphocytes, $C D 4^{+} T$ cells and $C D 8^{+} T$ cells were significant more in LCR group $(P<0.05)$ on POD 4, while there was no difference in the CD45RO ${ }^{+} T$ or NK cell numbers between the two groups. Cellular immune responds were similar between the two groups on POD1 and POD7.

Conclusions: Laparoscopic colorectal resection gets less surgery stress and short-term advantages compared with open resection. Cellular immune respond appears to be less affected by laparoscopic colorectal resection when compared with open resection.

\section{Background}

Colorectal cancer is one kind of frequent malignant tumors of the digestive tract which gets high morbidity and mortality allover the world. Along with peoples' transition of life styles and food habits, the incidence rate of colorectal cancer gets rising for the past few years. Nowadays, surgery is still to remain as a principal method to treat colorectal cancer. Since the first laparoscopic cholecystectomy performed in France by Phillippe Mouriat of

\footnotetext{
* Correspondence: qiuwryb@onlin.sh.cn

† Contributed equally

'Department of General Surgery, Affiliated First People's Hospital, Shanghai Jiao Tong University, Shanghai, PR China, 200080

Full list of author information is available at the end of the article
}

Lyons in 1987 [1], the development of minimally invasive surgery has allowed major changes in the surgical treatment of various benign and malignant diseases, especially because it limits surgical trauma [2]. During recent years, the laparoscopic approach has developed as an interesting therapeutic alternative for the resection of various colorectal diseases [3-6]. In China, The first series of laparoscopic colorectal resection was reported by Shanghai Ruijin Hospital in 1993. Since 2000, there has been a remarkable increase in this field. Laparoscopic colorectal surgery has been routinely performed in most of the general teaching hospitals [7]. This procedure has been shown to be feasible in most patients with malignant 
disease and can be performed with faster recovery and shorter hospitalization than the open approach [8-11].

Despite the promising clinical results, less information is available regarding the perioperative immunological effects of laparoscopic surgery when compared with the open surgery. This prospective clinical study was of major clinical interest because the reduced surgical trauma should result in reduced postoperative immune, especially cellular immune dysfunction in patients undergoing laparoscopic surgery, thus contributing to clinical and oncologic advantages for these patients.

Until now, it has been reported that the degree of postoperative inflammatory is reduced after laparoscopic surgery [12,13]. Other groups also observed significantly better preservation of cell-mediated immunity after laparoscopic vs open colorectal surgery $[14,15]$. Furthermore, it has been observed that cell-mediated immunity, as assessed by delayed-type hypersensitivity testing in humans, is better preserved after laparoscopic vs open colorectal resection [16].

Our study was performed to evalute perioperative immune parameters in 68 patients with colorectal cancer. We herein analyzed the effects of laparoscopic and open surgery on proinflammatory $\mathrm{C}$-reative protein(CRP) levels. Furthermore, we measured lymphocyte subpopulations, leukocyte and neutrophils counts, and circulating natural killer(NK) cells before surgery and on days1, 4, and 7 after surgery. This study, therefore, allowed assessment of the effects of laparoscopic and conventional open colorectal surgery on cellular immune responses after major abdominal surgery.

\section{Methods \\ Patients}

Between Mar 2009 and Sep 2009, 68 patients diagnosed with primary colorectal cancer were enrolled into this study. All patients, who underwent surgical treatment at Affiliated First People's Hospital of Shanghai Jiao Tong University, gave informed consent for the use of blood samples in this study. Among these prospectively enrolled patients, 35 underwent laparoscopic colorectal resection (LCR) and 33 underwent open colorectal resection(OCR).

Patients with colorectal cancer in stage IV intestinal obstruction, recurrence tumor, preoperative chemoradiation, palliative surgery and perioperative complications were excluded from the study. Patients with diabetes mellitus, use of steroids and with other immunological diseases were excluded from the study as well, since these events could impair the cellular immune responses after surgery.

Informed consent was obtained from all patients, who underwent surgical treatment at Affiliated First People's Hospital of Shanghai Jiao Tong University. Our research have been performed with the approval of the ethics committee of Affiliated First People's Hospital of Shanghai Jiao Tong University.

\section{Surgery Method}

Minimally invasive colorectal surgery was performed as a laparoscopic-assisted procedure with removal of the resected specimen via a horizontal minilaparotomy $(5 \mathrm{~cm})$ just above the mons pubis. Laparoscopic surgery was done using a 5-trocar technique with 1 trocar $(10 \mathrm{~mm})$ inserted via a paraumbilical incision (camera port). Four additional $(5 \mathrm{~mm})$ trocars were inserted in the right and left lower abdomen. After removal of the resected specimen and preparation of the stapler anastomosis, we closed the minilaparotomy and reintroduced pneumoperitoneum.

Conventional colorectal surgery was performed via a vertical midline incision or a transrectal incision ranging from 10 to $15 \mathrm{~cm}$ above the umbilicus to the mons pubis. After we removed the resected specimen, we performed a stapler or a handwork anastomosis.

\section{Blood test}

Peripheral venous blood samples were taken prior to surgery as well as on postoperative days(POD) 1,4 and 7 . Leukocyte number, absolute number and percentage of total lymphocytes for all the investigated patients were measured using an automated blood cell counter (Beckman LH750, America). CRP was measured using a CRP hematology analyzer (ABX Diagnostics Micros, France). The parameters of cellular immunity $\left(\mathrm{CD}^{+}, \mathrm{CD}^{+}, \mathrm{CD} 8^{+}\right.$, $\mathrm{CD}_{16}{ }^{+}, \mathrm{CD}^{2} 6^{+}$and $\mathrm{CD} 45 \mathrm{RO}^{+}$) were determined by flow cytometry (Beckman Coulter EpicsXL, America). The monoclonal antibodies used for immunophentyping were purchased from Beckman Coulter (France). The samples were prepared by labeling $50 \mu \mathrm{L}$ of whole blood with $10 \mu \mathrm{L}$ of monoclonal antibody for 10 minutes in the dark using the antibody combinations. Helper T lymphocytes were determined by UCHT1/13B8.2 indexed for CD3/ $\mathrm{CD} 4$. Cytotoxic $\mathrm{T}$ lymphocytes were determined by UCHT1/B9.11 indexed for CD3/CD8. Natural killer cells were determined by 3G8/N901 indexed for CD16/CD56. Memory $\mathrm{T}$ lymphocytes were determined by UCHL1 indexed for CD45RO.

\section{Statistical analysis}

Data were analyzed using SAS9.13 statistical package, analysis of variance on $t$ test, Wilcoxon rank test and $\chi^{2}$ test. Differences were considerd statistically significant at $P<0.05$.

\section{Results}

\section{Baseline characteristics}

68 patients were enrolled into this study. Among the 35 LCR patients, 20 were male and 15 were female. The 
mean patient age was $68.43 \pm 11.16$ years in LCR group. Among the 33 OCR patients, 20 were male and 13 were female. The mean patient age was $68.33 \pm 12.69$ years in OCR group. There was no difference in the age, gender and tumor status between the two groups (Table 1).

\section{Perioperative complications}

Between Mar 2009 and Sep 2009, in our department, 3 patients in LCR group and 2 patients in OCR group suffered from postoperative complications. In LCR group, anastomotic leakage occurred in 2 patients with low-set rectal cancer and paralytic ileus occurred in 1 patient with rectal cancer. All these 3 patients were cured after expectant treatment. In OCR group, incision disruption occurred in 1 patient with transverse colonic cancer and the patient accepted emergent suturation. The other patient with rectal cancer sufferring from paralytic ileus was cured after expectant treatment. There was no difference in postoperative morbidity between the two groups. Considering cellular immunity impaired by postoperative complications, which might impact cellular immune outcomes caused by selection of surgery, we excluded these 5 patients and selected 68 donors into this study at last.

\section{Surgery effects and postoperative recovery}

The operating time was a little longer in the laparoscopic group $(P>0.05)$, but the blood loss was less $(P=0.039)$.
Patients with laparoscopic resection had earlier return of bowel function and earlier resumption of diet as well as shorter median hospital stay $(P<0.001)$ (Table 2$)$.

\section{Proinflammatory mediators}

After both laparoscopic and open colorectal surgery, we observed a significant increase of circulating CRP levels and this increase was similar between the two groups on POD 1 and POD 4. But on POD 7, CRP descended to the preoperative level in LCR group, while CRP was still significantly higher than the preoperative level in OCR group (Table 3, Figure 1).

\section{Markers of cellular immune responses}

Before the operations, there was no difference in the count of leukocyte, neutrophils, lymphocytes, $\mathrm{CD} 4^{+} \mathrm{T}$ cells, $\mathrm{CD} 8$ ${ }^{+} \mathrm{T}$ cells, $\mathrm{CD} 45 \mathrm{RO}^{+} \mathrm{T}$ cells and NK cells between the two groups. On POD 1, in both two groups, the count of leukocyte and neutrophils significantly rose and the count of lymphocytes, $\mathrm{CD} 4^{+} \mathrm{T}$ cells, $\mathrm{CD} 8^{+} \mathrm{T}$ cells, $\mathrm{CD} 45 \mathrm{RO}^{+} \mathrm{T}$ cells and NK cells significantly descended, while there was no difference between the two groups. On POD 4, the count of lymphocytes, $\mathrm{CD} 4^{+} \mathrm{T}$ cells and $\mathrm{CD} 8^{+} \mathrm{T}$ cells were significantly higher in LCR group than OCR group. The count of CD45RO ${ }^{+} \mathrm{T}$ cells in LCR group also had significant rise trend compared with OCR group, while the count of NK cells in OCR group still had continuous depression trend

Table 1 Baseline characteristics

\begin{tabular}{|c|c|c|c|c|}
\hline & LCR $(n=35)$ & OCR $(n=33)$ & statistic & $P$ value \\
\hline \multicolumn{5}{|l|}{ Gender } \\
\hline Male & 20 & 20 & $\chi^{2}=0.084$ & 0.772 \\
\hline Female & 15 & 13 & & \\
\hline Age $(y r)$ & $68.43 \pm 11.16$ & $68.33 \pm 12.69$ & $Z=0.055$ & 0.956 \\
\hline Height $(\mathrm{cm})$ & $165.77 \pm 8.23$ & $162.36 \pm 7.67$ & $t=1.760$ & 0.082 \\
\hline Weight (kg) & $63.30 \pm 10.82$ & $60.98 \pm 11.33$ & $Z=-1.032$ & 0.302 \\
\hline BMI $\left(\mathrm{kg} / \mathrm{m}^{2}\right)$ & $22.95 \pm 2.88$ & $22.91 \pm 3.22$ & $t=0.060$ & 0.956 \\
\hline \multicolumn{5}{|l|}{ Tumor position } \\
\hline Left hemicolon & 5 & 2 & $\chi^{2}=0.002$ & 0.564 \\
\hline Transverse colon & 1 & 2 & & \\
\hline Right hemicolon & 9 & 13 & & \\
\hline Sigmoid colon & 7 & 4 & & \\
\hline Rectum & 13 & 12 & & \\
\hline \multicolumn{5}{|l|}{ Tumor staging of TNM } \\
\hline 0 & 2 & 0 & $\chi^{2}=0.009$ & 0.405 \\
\hline । & 2 & 3 & & \\
\hline$\|$ & 20 & 15 & & \\
\hline III & 11 & 15 & & \\
\hline \multicolumn{5}{|l|}{ ASA classification } \\
\hline । & 2 & 0 & $\chi^{2}=-0.083$ & 0.934 \\
\hline$\|$ & 26 & 28 & & \\
\hline III & 7 & 5 & & \\
\hline
\end{tabular}

The baseline characteristics were similar between the two groups $(P>0.05)$. 
Table 2 Surgery effects and postoperative recovery

\begin{tabular}{lcccc}
\hline & LCR $(\mathbf{n}=\mathbf{3 5})$ & OCR $(\mathbf{n}=\mathbf{3 3})$ & $\boldsymbol{Z}$ value & $\boldsymbol{P}$ value \\
\hline Operating time (min) & $137.29 \pm 34.58$ & $130.61 \pm 36.72$ & -0.752 & 0.452 \\
Blood loss (ml) & $117.27 \pm 65.21$ & $159.39 \pm 83.40$ & -2.064 & $0.039^{*}$ \\
Enterokinesia (d) & $1.86 \pm 1.09$ & $3.00 \pm 0.92$ & 4.481 & $<0.001^{*}$ \\
Outgas (d) & $2.54 \pm 1.38$ & $3.78 \pm 1.18$ & 4.144 & $<.001^{*}$ \\
Out-of-bed activity (d) & $2.80 \pm 1.26$ & $3.38 \pm 1.07$ & 2.385 & $0.017^{*}$ \\
Fluid (d) & $3.14 \pm 1.35$ & $5.27 \pm 1.28$ & 5.624 & $<0.001^{*}$ \\
Semifluid (d) & $5.47 \pm 1.50$ & $7.97 \pm 1.31$ & 5.559 & $<0.001^{*}$ \\
Postoperative hospital stay (d) & $9.88 \pm 4.02$ & $14.06 \pm 1.46$ & 5.896 & $<0.001^{*}$ \\
Total hospital stay (d) & $17.91 \pm 5.71$ & $20.74 \pm 2.42$ & 3.740 & $<0.001^{*}$ \\
\hline
\end{tabular}

LCR group had more operating time $(P>0.05)$ but less blood loss $(P<0.05)$ than OCR group. Patients with laparoscopic resection had earlier return of bowel function and earlier resumption of diet as well as shorter median hospital stay $(P<0.05)$.

compared with LCR group. On POD 7, the count of $\mathrm{CD} 4^{+} \mathrm{T}$ cells, $\mathrm{CD} 8^{+} \mathrm{T}$ cells and $\mathrm{CD} 45 \mathrm{RO}^{+} \mathrm{T}$ cells rose to the preoperative levels in LCR group. In OCR group, the count of $\mathrm{CD}^{+}{ }^{+} \mathrm{T}$ cells and $\mathrm{CD} 45 \mathrm{RO}^{+} \mathrm{T}$ cells also rose to the preoperative levels, while the count of $\mathrm{CD}^{+} \mathrm{T}$ cells was still significantly depressed compared with the preoperative level (Table 3, Figure 2, 3, 4, 5 and 6).

\section{Discussion}

Colorectal cancer is one kind of frequent malignant tumors of the digestive tract which gets high morbidity and mortality all over the world. Nowadays, surgery is still to remain as a principal method to treat colorectal cancer. On the other hand, tumor immunity, mainly defined as the immune responses in the body against tumor, acts an important role during the process when patients fight against tomors. When tumor antigens were recognised by antigen presenting cells(APC), they were processed as peptides, and these peptides presented by APC acted as first and second signals to activate naive $\mathrm{CD} 4^{+} \mathrm{T}$ cells and $\mathrm{CD} 8^{+} \mathrm{T}$ cells. As naive $\mathrm{CD} 4^{+} \mathrm{T}$ cells and $\mathrm{CD} 8^{+} \mathrm{T}$ cells received these signals, they differentiated into Th0 cells and PCTL. When Th0 cells received different allostimulatory signals, they were activated as Th1 and Th2 cells. IL-4 secreted by Th2 cells acted as allostimulatory signal to activate B cells. Activated B cells could secrete generous tumor specific antibodies and killed tumor cells through complement dependent cytotoxicity(CDC) and antibody dependent cell-mediated cytotoxicity(ADCC). IFN- $\gamma$ secreted by Th1 cells acted as allostimulatory signal to activate pCTL. Activated CTL could kill tumor cells directly. Besides, IFN- $\gamma$ secreted by Th1 cells could enhance the activity of NK cells and $\mathrm{M} \phi$, which could fight against tumors through ADCC. After antitumor immune responses, part of activated $\mathrm{T}$ cells could differentiate into memory $\mathrm{T}$ cells $\left(\mathrm{CD} 45 \mathrm{RO}^{+} \mathrm{T}\right.$ cells), which had quick reaction against tumor cells in twice antitumor immune responses $[17,18]$. It can be seen that cellular immunity acts an predominant role in tumor immunity.
Although surgery is regarded as the most important way in tumor therapy, many reports have confirmed that surgery stress has great depressant effect on cellular immunity in the body, which would bring negative influence to prognosis of patients $[16,19,20]$. So to think of a way to decrease surgery stress as well as the influence of cellular immunity becomes quite important.

The development of minimally invasive surgery has allowed major changes in the surgical treatment of various benign and malignant diseases, especially because it limits surgical trauma. Since Jacobs [21] reported the first case of laparoscopic sigmoidectomy, during recent years, the laparoscopic approach has developed as an interesting therapeutic alternative for the resection of colorectal cancer. Because the surgical trauma is limited, the laparoscopic approach usually allows for a rapid return to preoperative activity levels with significantly shorter hospitalization.

This study found that the operating time of LCR group and OCR group were $137.29 \pm 34.58 \mathrm{~min}$ and $130.61 \pm$ $36.72 \mathrm{~min}$, prospectively. There was no difference between the two groups. Conventional versus laparoscopic assisted surgery in colorectal cancer (CLASSICC) [22], Colon cancer laparoscopic or open resection study group (COLOR) [6] and Lezoche [8] also observed similar results. Our findings shew that the intraoperative blood loss in LCR group and OCR group were $117.27 \pm 65.21 \mathrm{ml}$ and $159.39 \pm$ $83.40 \mathrm{ml}$, prospectively. We found the intraoperative blood loss was much less in LCR group. Barcelona [5] and COLOR [6] also observed similar outcomes as we did. Patients with laparoscopic resection had earlier return of bowel function and earlier resumption of diet as well as shorter median hospital stay. This observation confirmed findings reported by Breukink [23]. Our findings suggested that short-term quality-of-life benefits could be observed with LCR when compared with OCR.

Besides the promising clinical results, we focused on the perioperative cellular immunological effects of LCR when compared with OCR. 
Table 3 Summary of proinflammatory responses and cellular immunity

\begin{tabular}{|c|c|c|c|c|c|c|c|c|}
\hline \multirow[t]{2}{*}{ Immune mediators } & \multicolumn{4}{|c|}{ LCR $(n=35)$} & \multicolumn{4}{|c|}{ OCR $(n=33)$} \\
\hline & Preoperative & POD 1 & POD 4 & POD 7 & Preoperatvie & POD 1 & POD 4 & POD 7 \\
\hline WBC $\left(\times 10^{9} / L\right)$ & $6.10 \pm 1.68$ & $10.88 \pm 2.29^{\#}$ & $7.60 \pm 1.93^{\#}$ & $7.28 \pm 1.46^{\#}$ & $6.07 \pm 1.45$ & $12.21 \pm 4.10^{\#}$ & $8.24 \pm 2.52^{\#}$ & $7.96 \pm 2.34^{\#}$ \\
\hline Neutrophils $\left(\times 10^{9} / \mathrm{L}\right)$ & $3.81 \pm 1.62$ & $9.24 \pm 2.33^{\#}$ & $5.58 \pm 1.79^{\#}$ & $5.06 \pm 1.13^{\#}$ & $3.89 \pm 1.18$ & $10.44 \pm 3.91^{\#}$ & $6.28 \pm 2.19^{\#}$ & $5.58 \pm 1.81^{\#}$ \\
\hline Lymphocytes $\left(\times 10^{9} / \mathrm{L}\right)$ & $1.67 \pm 0.52$ & $0.99 \pm 0.41^{\#}$ & $1.24 \pm 0.39^{\# *}$ & $1.48 \pm 0.43^{\#}$ & $1.70 \pm 0.56$ & $1.16 \pm 0.38^{\#}$ & $1.06 \pm 0.41^{\# *}$ & $1.50 \pm 0.54^{\#}$ \\
\hline $\mathrm{CD}^{+} \mathrm{T}$ cells $\left(\times 10^{9} / \mathrm{L}\right)$ & $0.62 \pm 0.25$ & $0.32 \pm 0.13^{\#}$ & $0.51 \pm 0.20^{\# *}$ & $0.60 \pm 0.23$ & $0.62 \pm 0.28$ & $0.37 \pm 0.20^{\#}$ & $0.39 \pm 0.21^{\# *}$ & $0.59 \pm 0.26$ \\
\hline $\mathrm{CD}^{+} \mathrm{T}$ cells $\left(\times 10^{9} / \mathrm{L}\right)$ & $0.47 \pm 0.24$ & $0.28 \pm 0.13^{\#}$ & $0.33 \pm 0.13^{\# *}$ & $0.41 \pm 0.16$ & $0.43 \pm 0.19$ & $0.27 \pm 0.13^{\#}$ & $0.26 \pm 0.13^{\# *}$ & $0.38 \pm 0.22^{\#}$ \\
\hline $\mathrm{CD}^{2} 5 \mathrm{RO}^{+} \mathrm{T}$ cells $\left(\times 10^{9} / \mathrm{L}\right)$ & $0.52 \pm 0.20$ & $0.32 \pm 0.14^{\#}$ & $0.45 \pm 0.15^{\#}$ & $0.51 \pm 0.17$ & $0.55 \pm 0.27$ & $0.32 \pm 0.17^{\#}$ & $0.37 \pm 0.18^{\#}$ & $0.51 \pm 0.27$ \\
\hline NK cells $\left(\times 10^{9} / \mathrm{L}\right)$ & $0.29 \pm 0.21$ & $0.16 \pm 0.11^{\#}$ & $0.17 \pm 0.10^{\#}$ & $0.23 \pm 0.13^{\#}$ & $0.32 \pm 0.22$ & $0.18 \pm 0.16^{\#}$ & $0.14 \pm 0.14^{\#}$ & $0.25 \pm 0.22^{\#}$ \\
\hline $\mathrm{CRP}(\mathrm{mg} / \mathrm{L})$ & $11.93 \pm 20.56$ & $58.38 \pm 32.51^{\#}$ & $38.43 \pm 34.12^{\#}$ & $23.18 \pm 25.51$ & $8.87 \pm 12.44$ & $53.77 \pm 31.16^{\#}$ & $48.83 \pm 35.78^{\#}$ & $27.19 \pm 25.25^{\#}$ \\
\hline
\end{tabular}

${ }^{\#} P<0.05$, compared with preoperative levels;

${ }^{*} P<0.05$, compared between the two groups.

Especially, on POD 4, the count of lymphocytes, CD4 ${ }^{+} T$ cells and $\mathrm{CD}^{+} \mathrm{T}$ cells were significantly higher in LCR group than OCR group $(P<0.05)$. The count of CD45RO ${ }^{+} \mathrm{T}$ cells in $L C R$ group also had significant rise trend compared with OCR group $(P>0.05)$, while the count of NK cells in OCR group still had continuous depression trend compared with LCR group $(P>0.05)$. 


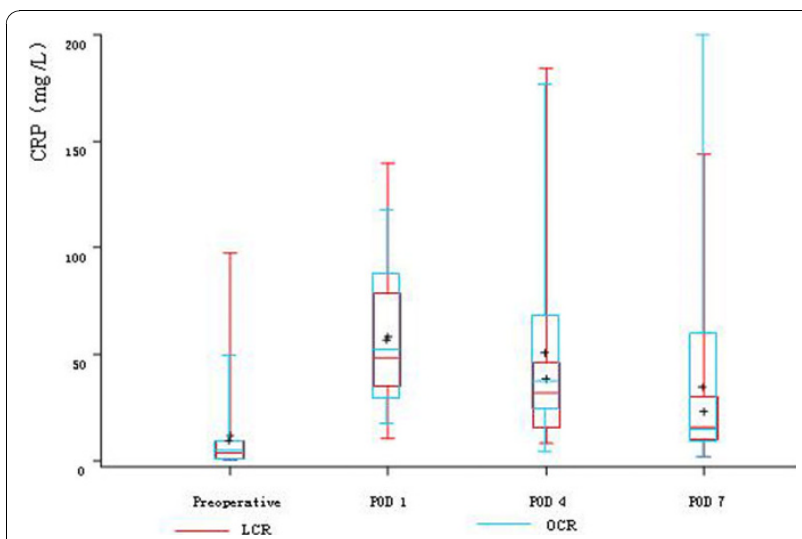

Figure 1 Summary of CRP between the two groups. On POD 1 and POD 4, the CRP levels were both significantly higher than the preoperative levels in both two groups $(P<0.05)$. But on POD 7 , CRP descended to the preoperative level in LCR group $(P>0.05)$, while CRP was still significantly higher than the preoperative level in OCR group $(P<0.05)$.

Many researches have confirmed that prognosis of cancers depends on invasion of tumors and immunoreaction of bodies. Paholyuk [24] found that NK cells played an important role in suppressing growth of colorectal cancers of stage II. Milašienè [25] reported that counts of CD $4^{+} \mathrm{T}$ cells, $\mathrm{CD}^{+} \mathrm{T}$ cells and NK cells directly correlated with long-term overall survivals of patients with colorectal cancers and gastric cancers of stage III.

Hiki [12] reported that in laparoscopy there was generally less manipulation and exposure of the intestine than in open surgery, with a further reduction in host inflammatory responses. Our findings shew that minimally invasive surgery resulted in a less pronounced proinflammatory response to surgical trauma. Jung [13] also got similar results in the research, who found

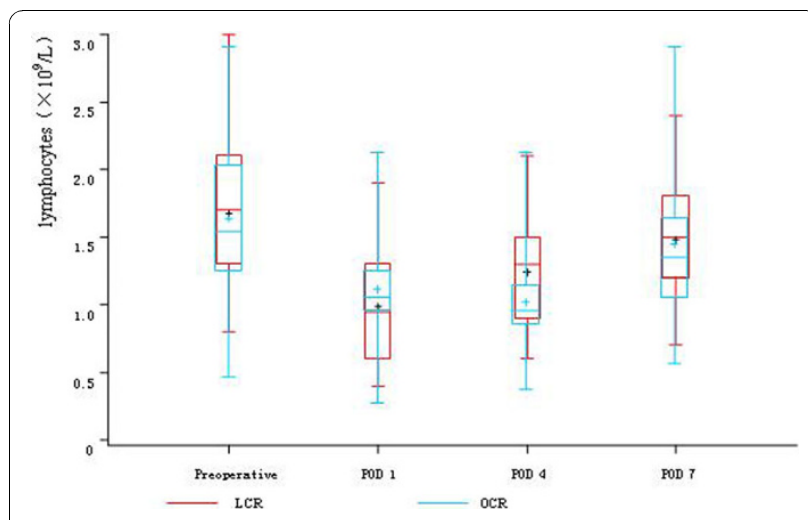

Figure 2 Cell count of lymphocytes between the two groups. On POD 1 and POD 7, in both two groups, the count of lymphocytes significantly descended $(P<0.05)$, while there was no difference between the two groups $(P>0.05)$. While on POD 4 , the count of lymphocytes was significantly higher in LCR group than OCR group $(P<0.05)$.

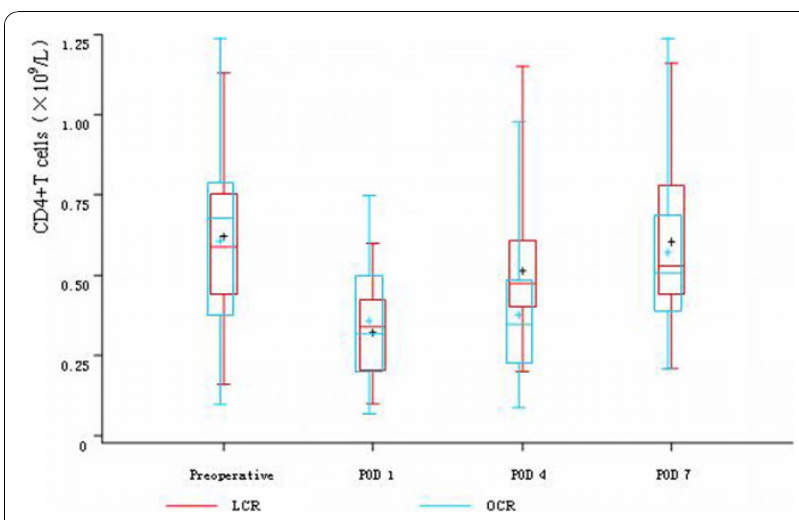

Figure 3 Cell count of $\mathrm{CD}^{+} \mathrm{T}$ cells between the two groups. On POD 1, in both two groups, the count of $C D 4^{+} \mathrm{T}$ cells significantly descended $(P<0.05)$, while there was no difference between the two groups $(P>0.05)$. While on POD 4 , the count of $C D 4^{+} T$ cells was significantly higher in LCR group than OCR group $(P<0.05)$. On POD 7, the count of $C D 4^{+} T$ cells rose to the preoperative level in both two groups.

laparoscopic surgery got less influence on CRP than open surgery.

Many researches have observed that there is a distinct immunologic advantage to laparoscopic surgery [26-29]. Our findings confirmed better preserved cellular immune responses in patients undergoing laparoscopic colorectal resections. The counts of $C D 4^{+} \mathrm{T}$ cells, $\mathrm{CD} 8^{+} \mathrm{T}$ cells,

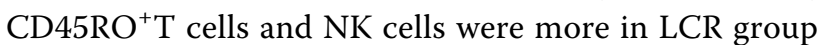
than OCR group, especially on POD 4. This observation was in agreement with the findings of Whelan [16], who also observed better preserved cellular immune responses in patients undergoing laparoscopic surgeries. Although

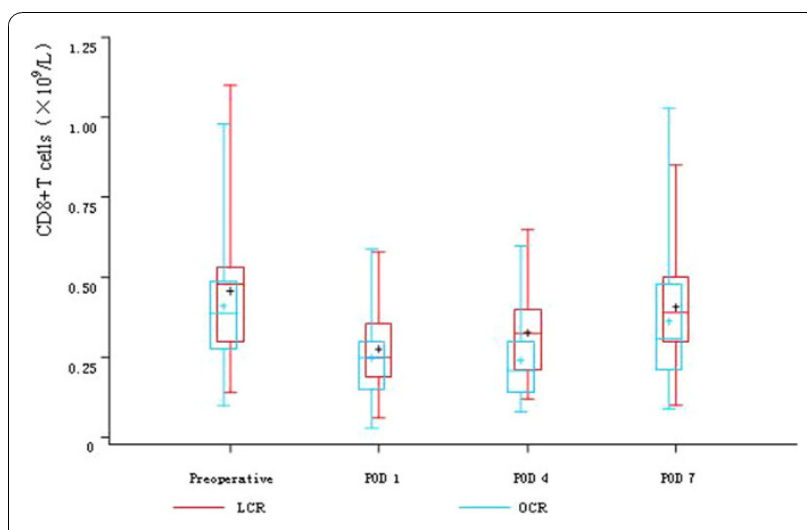

Figure 4 Cell count of $\mathrm{CD}^{+} \mathrm{T}$ cells between the two groups. On $P O D 1$, in both two groups, the count of $C D 8^{+} T$ cells significantly descended $(P<0.05)$, while there was no difference between the two groups $(P>0.05)$. While on POD 4 , the count of $C D 8^{+} T$ cells was significantly higher in $L C R$ group than OCR group $(P<0.05)$. On POD 7 , the count of $C D 8^{+} T$ cells rose to the preoperative level in LCR group, while in OCR group, the count of CD8 ${ }^{\top} T$ cells was still significantly depressed compared with the preoperative level $(P<0.05)$. 


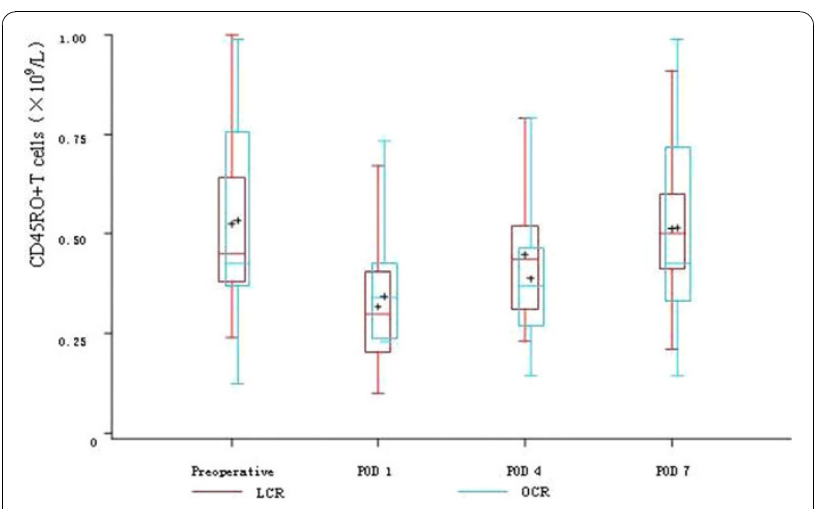

Figure 5 Cell count of $C D 45 \mathrm{RO}^{+} \mathrm{T}$ cells between the two groups. On POD 1, in both two groups, the count of $C D 45 R O^{+} T$ cells significantly descended $(P<0.05)$, while there was no difference between the two groups $(P>0.05)$. While on POD 4, The count of CD45RO ${ }^{+} T$ cells in LCR group had significant rise trend compared with OCR group $(P>0.05)$. On POD 7, the count of $\mathrm{CD}^{2} 5 \mathrm{RO}^{+} \mathrm{T}$ cells rose to the preoperative level in both two groups.

our findings were not completely comparable with the researches from Wichmann [14], we found similar change tendency of NK cells. Han [15] also reported that laparoscopic resections got less influence on cellular immune functions of the patients with colorectal cancers of stage III. Peng [30] found the perioperative immune response was less obvious after a laparoscopic procedure compared with a conventional approach in patients with renal cell carcinoma.

Compared with the previous research articles, our study more comprehensively reflected the progress of laparoscopic colorectal cancer radical resections and the improvement of cellular immune protection nowadays in Mainland of China.

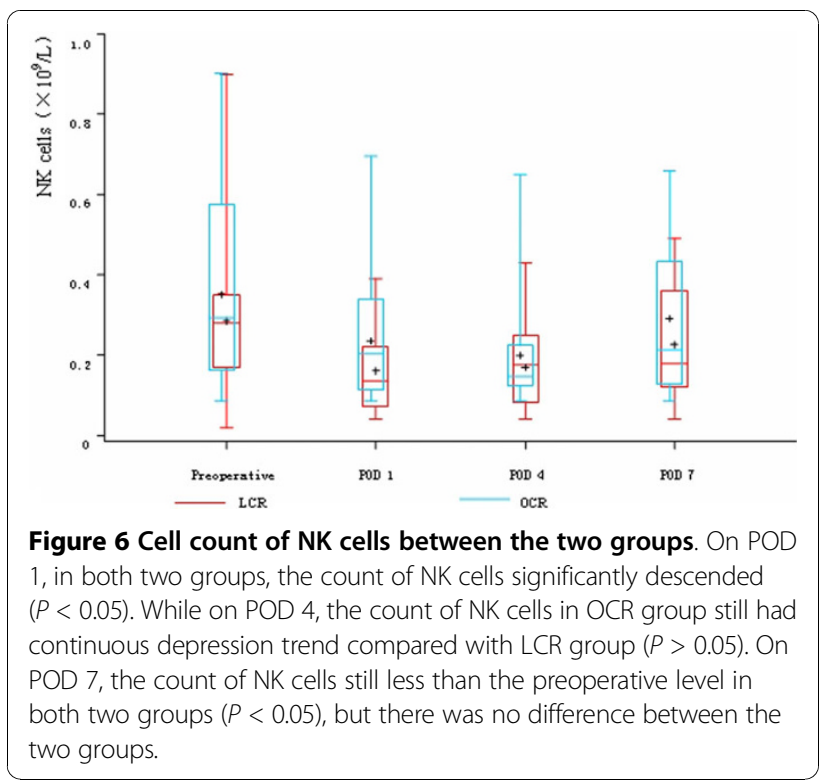

There is a suggestion that cancers demonstrate a more aggressive phenotype after open surgery, with the more profound immunosuppression contributing to more rapid cancer growth [31]. Milašienè [25] reported that better cellular immunity correlated with higher postoperative survival rates in patients. The long-term effects of better preserved cellular immune responses and its relationship with the prognosis of patients still remain obscure. However, we can assume that our observation of better preserved cellular immunity in patients after laparoscopic colorectal surgeries has beneficial effects on the prognosis of patients.

\section{Conclusions}

In conclusion, our study demonstrates that laparoscopic colorectal resection gets less surgery stress and shortterm advantages compared with open resection. Also, cellular immune respond appears to be less affected by laparoscopic colorectal resection when compared with open resection.

\section{Acknowledgements}

This study was supported by by a grant (No. SHDC12006102) awarded by fund for scientific research of Shanghai Shenkang Hospital Development Center.

\section{Author details}

'Department of General Surgery, Affiliated First People's Hospital, Shanghai Jiao Tong University, Shanghai, PR China, 200080. ²Digestive Endoscopy Center, Affiliated Huadong Hospital, Fudan University, Shanghai, PR China, 200040.

\section{Authors' contributions}

QZJ supervised the design of the experiments and carried out all the operations. HC conceived the study and drafted the manuscript. HRX was involved in blood test, drafting of the manuscript and design of the study. $\mathrm{JT}$ analysed and interpreted of data. HKJ and CJ participated in the design and coordination of the work involved. All authors read and approved the final manuscript.

\section{Competing interests}

The authors declare that they have no competing interests.

Received: 10 July 2010 Accepted: 28 October 2010

Published: 28 October 2010

\section{References}

1. Terblanche J: Laparoscopic cholecystectomy: a new milestone or a dangous innovation? HPB Surg 1991, 3:177-80.

2. COLOR Study Group: COLOR: a randomized clinical trial comparing laparoscopic and open resection for colon cancer. Dig Surg 2000, 17:617-22.

3. Clinical Outcomes of Surgical Therapy Study Group: A comparison of laparoscopically assisted and open colectomy for colon cancer. N Eng J Med 2004, 350:2050-9.

4. Leung KL, Kwok SP, Lam SC, Lee JF, Yiu RY, Ng SS, Lai PB, Lau WY: Laparoscopic resection of rectosigmoid carcinoma: prospective randomized trail. Lancet 2004, 363:1187-92.

5. Lacy AM, García-Valdecasas JC, Delgado S, Castells A, Taurá P, Piqué JM, Visa J: Laparoscopy-assisted colectomy versus open colectomy for treatment of non-metastatic colon cancer: a randomized trail. Lancet 2002, 359:2224-9.

6. Veldkamp R, Kuhry E, Hop WC, Jeekel J, Kazemier G, Bonjer HJ, Haglind E, Påhlman L, Cuesta MA, Msika S, Morino M, Lacy AM, COlon cancer Laparoscopic or Open Resection Study Group (COLOR): Laparoscopic 
surgery versus open surgery for colon cancer: short-term outcomes of a randomized trail. Lancet Oncol 2005, 6:477-84.

7. Guo W, Zhang ZT: Laparoscopic surgery in the mainland of China. Chin Med J (Engl) 2009, 122:2226-8.

8. Lezoche E, Feliciotti F, Guerrieri M, Paganini AM, De Sanctis A Campagnacci R, D'Ambrosio G: Laparoscopic versus open hemicolectomy for colon cancer. Surg Endosc 2002, 16:596-602.

9. Guillou PJ, Quirke P, Thorpe H, Walker J, Jayne DG, Smith AM, Heath RM, Brown JM, MRC CLASICC trial group: Short-term endpoints of conventional versus laparoscopic-assisted surgery in patients with colorectal cancer (MRC CLASSICC trail): multicentre, randomized controlled trail. Lancet 2005, 365:1718-26.

10. Feng B, Zheng MH, Mao ZH, Li JW, Lu AG, Wang ML, Hu WG, Dong F, Hu YY, Zang L, Li HW: Clinical advantages of laparoscopic colorectal cancer surgery in the elderly. Aging Clin Exp Res 2006, 18:191-5.

11. Zheng $\mathrm{MH}$ : The roles of laparoscopy in the surgical treatment of rectal cancer. Zhonghua Wai Ke Za Zhi 2009, 47:968-70.

12. Hiki N, Shimizu N, Yamaguchi H, Imamura K, Kami K, Kubota K, Kaminishi M: Manipulation of the small intestine as a cause of the increased inflammatory response after open compared with laparoscopic surgery. Br J Surg 2006, 93:195-204

13. Jung IK, Kim MC, Kim KH, Kwak JY, Jung GJ, Kim HH: Cellular and peritoneal immune response after radical laparoscopy-assisted and open gastrectomy for gastric cancer. J Surg Oncol 2008, 98:54-9.

14. Wichmann MW, Hüttl TP, Winter H, Spelsberg F, Angele MK, Heiss MM, Jauch KW: Immunological Effects of Laparoscopic vs Open Colorectal Surgery: a prospective clinical study. Arch Surg 2005, 140:692-7.

15. Han SA, Lee WY, Park CM, Yun SH, Chun HK: Comparison of immunologic outcomes of laparoscopic vs open approaches in clinical stage III colorectal cancer. Int J Colorectal Dis 2010, 25:631-8.

16. Whelan RL, Franklin M, Holubar SD, Donahue J, Fowler R, Munger C Doorman J, Balli JE, Glass J, Gonzalez JJ, Bessler M, Xie H, Treat M: Postoperative cell mediated immune response is better preserved after laparoscopic vs open colorectal resection in humans. Surg Endosc 2003, 17:972-8.

17. Zhou GY: Principles of Immunology. $2^{\text {nd }}$ Edition. Shanghai, Shanghai Science Technology Publishing Company 2008, 87:282-3.

18. Galon J, Fridman WH, Pagès F: The Adaptive Immunologic Microenvironment in Colorectal Cancer: A Novel Perspective. Cancer Res 2007, 67:1883-6.

19. Decker D, Schondorf M, Bidlingmaier F, Hirner A, von Ruecker AA: Surgical stress induces a shift in the type-1/type-2 T-helper cell balance, suggesting down-regulation of cell-mediated immunity commensurate to the trauma. Surgery 1996, 119:316-25.

20. Ishikawa M, Nishioka M, Hanaki N, Miyauchi T, Kashiwagi Y, Miki H: Hepatic resection leads to predominance of the T-helper-2 lymphocyte phenotype. Hepatology research 2004, 30:96-103.

21. Jacobs M, Verdeja JC, Goldstein HS: Minimally invasive colon resection (laparoscopic colectomy). Surg Laparosc Endosc 1991, 1:144-50.

22. Jayne DG, Guillou PJ, Thorpe H, Quirke P, Copeland J, Smith AM, Heath RM, Brown JM, UK MRC CLASICC Trial Group: Randomized trail of laparoscopic-assisted resection of colorectal carcinoma: 3-year results of the UK MRC CLASSICC Trail Group. J Clin Oncol 2007, 25:3061-8.

23. Breukink SO, Pierie JP, Grond AJ, Hoff C, Wiggers T, Meijerink WJ: Laparoscopic versus open total mesorectal excision: a case-control study. Int J Colorectal Dis 2005, 20:428-33.

24. Paholyuk TD, Zaharzeva LM, Koshel KV, Oliynichenko GP, Berezhnaya NM: Stage of differentiation, proliferative index of tumor cells and cytotoxic activity of peripheral blood lymphocytes in colorectal cancer patients. Exp Oncol 2004, 26:161-3.

25. Milašienè V, Stratilatovas E, Norkienè V: The importance of T-lymphocyte subsets on overall survival of colorectal and gastric cancer patients. Medicina (Kaunas) 2007, 43:548-54.

26. Novitsky YW, Litwin DE, Callery MP: The net immunologic advantage of laparoscopic surgery. Surg Endosc 2004, 18:1411-9.

27. Corrigan M, Cahill RA, Redmond HP: The immunomodulatory effects of laparoscopic surgery. Surg Laparosc Endosc Percutan Tech 2007, 17:256-61.

28. Matsumoto ED, Margulis V, Tunc L, Taylor GD, Duchene D, Johnson DB, Pearle MS, Cadeddu JA: Cytokine response to surgical stress: comparison of pure laparoscopic, hand-assisted laparoscopic, and open nephrectomy. J Endourol 2005, 19:1140-5.
29. Sáenz J, Asuero MS, Villafruela J, Correa C, Galindo J, Cuevas B, Galindo J, Páez A, Linares A, Pascual J, Marcén R, Burgos FJ: Immunohumeral response during laparoscopic and open living donor nephrectomy: an experimental model. Transplant Proc 2007, 39:2102-4.

30. Peng B, Zheng JH, Li H: Effect of retroperitoneal laparoscopic radical nephrectomy of renal carcinoma (nephroma) on perioperative cell immunity. J Endourol 2008, 22:2161-4.

31. Sylla P, Kirman I, Whelan RL: Immunological advantages of advanced laparoscopy. Surg Clin North Am 2005, 85:1-18.

\section{Pre-publication history}

The pre-publication history for this paper can be accessed here: http://www.biomedcentral.com/1471-230X/10/127/prepub

doi:10.1186/1471-230X-10-127

Cite this article as: Huang et al:: Laparoscopic and open resection for colorectal cancer: an evaluation of cellular immunity. BMC

Gastroenterology 2010 10:127.

\section{Submit your next manuscript to BioMed Central and take full advantage of:}

- Convenient online submission

- Thorough peer review

- No space constraints or color figure charges

- Immediate publication on acceptance

- Inclusion in PubMed, CAS, Scopus and Google Scholar

- Research which is freely available for redistribution

Submit your manuscript at www.biomedcentral.com/submit
C) Biomed Central 